\title{
A Review of Capital Structure Theory Using a Bibliometric Analysis
}

\author{
Denis Marinšek ${ }^{1}$
}

\begin{abstract}
Author citation and co-citation analysis is a simple, yet powerful educational tool for detecting the most relevant papers from any research field. I demonstrate its use and graphically show a chronological development of capital structure theory, which highlights the most important contributions. I then systematically present the capital structure theory, starting with Modigliani \& Miller's irrelevance theorem, and continue with four alternative explanations of firm capital structure behaviour. This paper is particularly useful for PhD students and junior researchers who need to familiarize with the literature of their own research field, and for those, interested in the up-todate review on capital structure theory.
\end{abstract}

\section{Introduction}

In a plethora of literature, finding key works and establish clear connections among them can be challenging. This paper addresses this issue, explaining how bibliometrics (i.e. citation and co-citation analysis with software BibExcel, and graphical presentation with software Pajek) can be applied to any research topic. The high importance of using innovative educational methods as learning aids was elaborated by Plumb \& Zamfir (2011) and Pocatilu \& Ciurea (2011). However, Dospinescu et al. (2011) found that students are often not enough informed about modern internet learning methods. I show that bibliometric analysis is a powerful educational tool, which offers a unique insight into a literature review.

Bibliometrics is used for detecting connections among different schools of thought and offers greater objectivity, which is a result of the outcome of a composite judgment of many citing authors (Bayer, Smart, \& McLaughlin, 1990). Moreover, it helps to determine the most influential papers, detect leading scholars, and offer different graphical presentations of development of any research field (e.g. chronological overview, detecting theory streams, etc.). Besides, it can save a lot of time because it immediately directs a researcher to the most crucial papers, which should be the base for building a new research.

\footnotetext{
1 Denis Marinšek, Faculty of Economics, Kardeljeva ploscad 17, 1000 Ljubljana; denis.marinsek@ef.uni-lj.si
} 
In this paper bibliometrics is applied to the literature on capital structure theory. To the best of my knowledge this kind of analysis has never been performed on the capital structure literature. The graphical presentation of bibliometric findings shows that a modern capital structure theory began in the late fifties with the irrelevance theorem by Modigliani \& Miller (1958), and that the theory developed from a neoclassical theory of the firm, which can be traced back into 1930s. As an answer to the irrelevance theorem, two theories of capital structure emerged: the trade-off theory (Jensen \& Meckling, 1976), and the pecking order hypothesis (Myers \& Majluf, 1984), both trying to explain observed behavior of firm's capital structure choices. More recently, the dynamic version of trade-off theory and equity market timing theory received a strong empirical support.

This paper has thus two goals. In section 2 it directs a reader to the literature on bibliometric tools, and demonstrates how they can be applied to facilitate a proper understanding of a chosen research topic. In section 3 it offers a comprehensive overview of capital structure theory from the beginnings to the most recently published articles. Conclusion summarizes the main findings of this paper.

\section{Bibliometric analysis as an educational tool}

Citation and co-citation analysis is performed on 400 English papers from the ISI Web of Science database (Thomson Reuters, 2013), related to the capital structure theory and published until February 2013. The database consists of three citation sources: Science Citation Index Expended (1970-present), Social Sciences Citation Index (1970-present), and Arts \& Humanities Citation Index (1975-present). At the time of downloading the database of articles, the last refresh of the database was on 22nd February 2013. The articles were found with the use of keywords: "Theory of capital structure" or "Modigliani-Miller theorem" or "Pecking order theory" or "Trade-off theory" or "Optimal debt level" or "Optimal leverage" or "Leverage and firm's performance" or "Financing decision" or "Target capital structure" or "Modern capital structure theory". With this search inquiry 8,980 articles were found. Out of all results, only English articles from four Web of Science categories were retained: Economics, Business Finance, Management, and Business. This step reduced the database to 4,120 articles. Further, abstracts of all potentially interesting articles were analyzed and articles that were not related to the capital structure theory were excluded. Finally, 400 most relevant articles for capital structure research were kept, which were the base for citation and co-citation analysis. For a detailed overview on various bibliometric methods, see White \& Belvar (1981), Bayer, Smart \& McLaughlin (1990) and De Bellis (2009).

\subsection{Citation analysis}

Figure 1 shows distribution of 400 primary articles by year of publishing (number of published articles in the year 2013 is not directly comparable since only 
the first two months are included), showing that the majority of papers were published more recently. Over the observed period, the average number of citations per paper is 132.39 and $\mathrm{h}$-index is 90 . This means that there are 90 papers among 400 primary papers that have at least 90 citations

Figure 1: Distribution of primary papers by the year of publishing

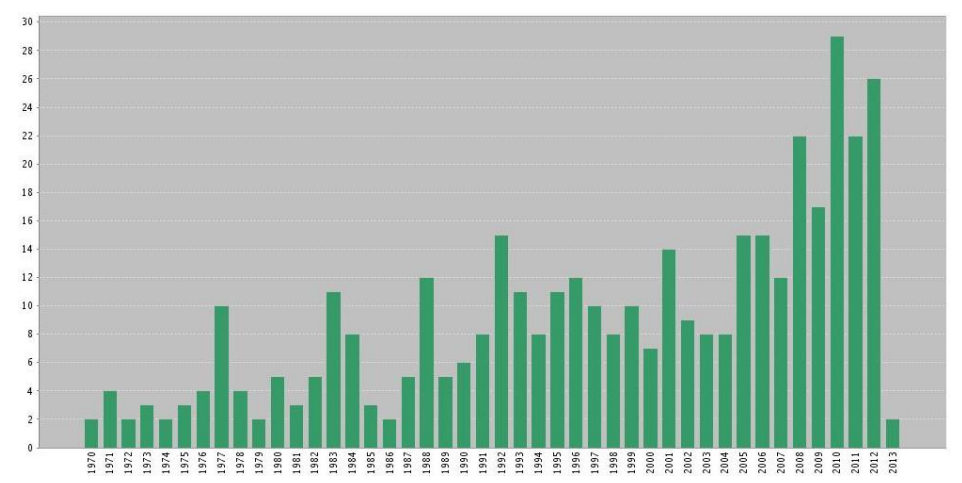

ISI Web of Science, 2013.

Moreover, Figure 2 demonstrates where these 400 primary papers were published. This can be performed by extracting authors' addresses with software BibExcel, and then utilizing GPS Visualizer (Persson, 2009).

Figure 2: Geographical locations of authors of primary papers

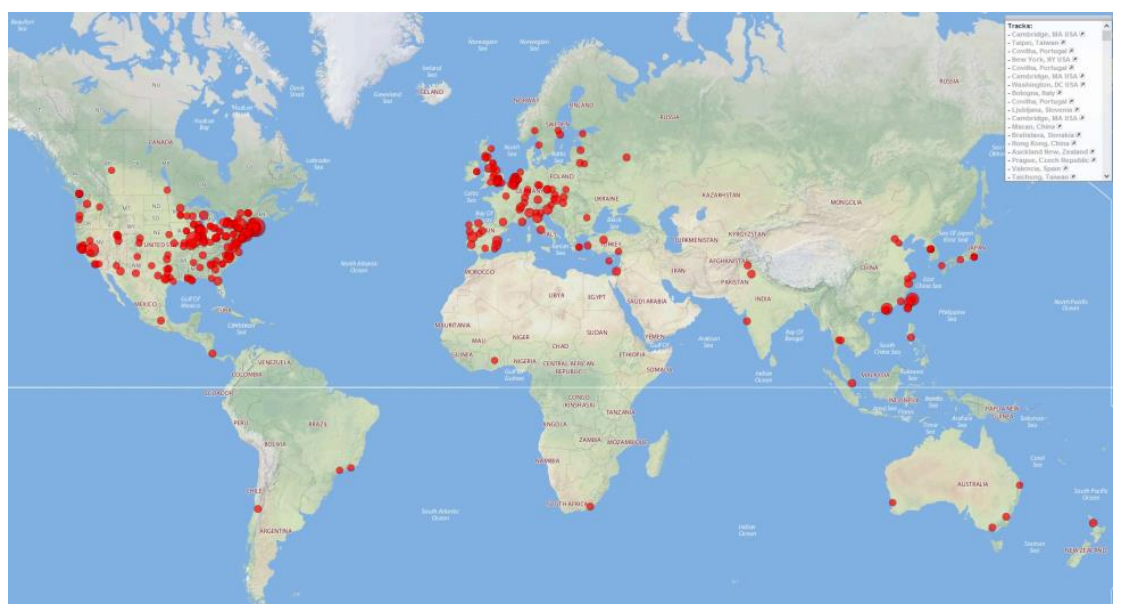

ISI Web of Science, 2013.

\subsection{Co-citation analysis}

After analyzing primary papers, the analysis of the target papers (i.e. papers that are citied within primary papers) is performed - the co-citation analysis. This is the analysis of joint occurrence of target papers within primary papers. Cooccurrence analysis, performed with the use of BibExcel software, is therefore the study of mutual appearances of pairs of units in analyzed bibliographic records (Persson, Danell, \& Wiborg Schneider, 2009). Authors, which co-occur together, are the base for the analysis of different schools of thoughts.

Table 1 shows the most important journals where target papers were published (i.e. frequency of occurrence of journals within the references of 400 primary 
papers). This can help as an orientation where further research on this topic can be published.

Table 1: Journals, which published the target articles

\begin{tabular}{|cc|}
\hline frequency & Journal name \\
\hline 2723 & The Journal of Finance \\
2005 & Journal of Financial Economics \\
746 & American Economic Review \\
369 & Review of Financial Studies \\
350 & Journal of Political Economy \\
271 & Journal of Financial and Quant. analysis \\
236 & Financial Management \\
211 & Quarterly Journal of Economics \\
210 & Journal of Business \\
195 & Bell Journal of Economics \\
184 & Econometrica \\
131 & Review of Economic Studies \\
\hline
\end{tabular}

ISI Web of Science, 2013.

Additionally, Table 2 shows the frequency of citations of the most cited target articles by 400 primary articles, denoted by $f$. This is the list of the most influential papers in the capital structure theory.

Table 2: Most frequently cited references by 400 primary articles

\begin{tabular}{|cl|cl|}
\hline$f$ & First author, year and publication & $f$ & First author, year and publication \\
\hline 169 & Jensen M, 1976, V3, P305, J Financ Econ & 49 & Stulz R, 1990, V26, P3, J Financ Econ \\
144 & Modigliani F, 1958, V48, P261, Am Econ Rev & 48 & MacKie-Mason J, 1990, V45, P1471, J Financ \\
141 & Myers S, 1977, V5, P147, J Financ Econ & 47 & Frank M, 2003, V67, P217, J Financ Econ \\
136 & Myers S, 1984, V13, P187, J Financ Econ & 47 & Marsh P, 1982, V37, P121, J Financ \\
122 & Titman S, 1988, V43, P1, J Financ & 46 & Baker M, 2002, V57, P1, J Financ \\
117 & Rajan R, 1995, V50, P1421, J Financ & 44 & Fischer E, 1989, V44, P19, J Financ \\
113 & Jensen M, 1986, V76, P323, Am Econ Rev & 42 & Graham J, 2001, V60, P187, J Financ Econ \\
95 & Myers S, 1984, V39, P575, J Financ & 41 & Titman S, 1984, V13, P137, J Financ Econ \\
85 & Harris M, 1991, V46, P297, J Financ & 36 & Leary M, 2005, V60, P2575, J Financ \\
81 & Modigliani F, 1963, V53, P433, Am Econ Rev & 35 & Welch I, 2004, V112, P106, J Polit Econ \\
80 & Bradley M, 1984, V39, P857, J Financ & 35 & Booth L, 2001, V56, P87, J Financ \\
73 & Miller M, 1977, V32, P261, J Financ & 34 & Kraus A, 1973, V28, P911, J Financ \\
73 & DeAngelo H, 1980, V8, P3, J Financ Econ & 32 & Smith C, 1979, V7, P117, J Financ Econ \\
70 & Shyam-Sunder L, 1999, V51, P219, J Financ Econ & 32 & Graham J, 2000, V55, P1901, J Financ \\
70 & Fama E, 2002, V15, P1, Rev Financ Stud & 31 & Flannery M, 2006, V79, P469, J Financ Econ \\
67 & Ross S, 1977, V8, P23, Bell J Econ & 30 & Leland H, 1977, V32, P371, J Financ \\
55 & Hovakim. A, 2001, V36, P1, J Financ Quant Anal & 30 & Jalilvand A, 1984, V39, P127, J Financ \\
\hline
\end{tabular}

With information gathered from citation and co-citation analysis, and with the help of Pajek software (Batagelj \& Mrvar, 1998; Persson, 2009b), Figure 3 presents 81 most important papers from the capital structure theory, i.e. papers that were most often cited by primary papers (data for drawing this figure are published as a supplementary information). The size of the circle represents the importance of a paper by number of citations, while the thickness of lines among papers depends on the number of co-citations among them. Additionally, papers are presented in a chronological order from the earliest papers on the top of the figure to the most recent 
ones at the bottom (each year has a unique color). In the following sections of this paper, the theory of capital structure is presented by closely following the findings from Figure 3.

\section{Modern capital structure theory}

Capital structure theory emerged from the neoclassical theory of the firm, which began with Berle \& Means (1932) and was continued by Coase (1937). On the basis of their work, two separate theories developed, both trying to explain what a firm is and how it operates. The first one is the agency cost theory (Jensen \& Meckling, 1976) that advocates a firm's existence because of its positive effects, created by a team production. The second one is the property rights theory (Demsetz, 1967) that concentrates on the contractual relationships within the firm. Both theories were the foundation for the modern capital structure theory, which began in the late fifties with the irrelevance theorem.

In 1958, Modigliani \& Miller (hereafter M\&M) published an influential article The cost of capital, corporation finance and the theory of investments, which was based on the neoclassical definition of the firm. Before this work, there was no generally accepted theory of the capital structure (Frank \& Goyal, 2008). In the article, authors assumed numerous unrealistic assumptions, which were, however, gradually omitted in their further publishing (e.g. maximization of the shareholders' value is the only goal of a firm; firm is financed only with equity and debt; there are no taxes; individuals can borrow and lend at the risk-free rate; markets have no frictions; firms operate in competitive markets; there is no asymmetric information; etc.).

Under these assumptions two propositions were made. The first proposition says that the value of a levered firm is equal to the value of an unlevered firm. M\&M argued that if two firms were identical (if generated the same cash flow), but differed only in their capital structures, then arbitrage opportunities would force values of both firms to become equal. As a result, the leverage has no effect on the market value of a firm. However, Baxter (1967) soon argued that with a high level of indebtedness, the 'risk of ruin' becomes very real and cannot be nullified by arbitrage. He concluded that when reliance on the financial debt is small, the tax-shelter effect dominates, but as soon as leverage increases too much, risk of ruin prevails. The same conclusion was proposed by Donaldson (1961), Robichek \& Myers (1966) and Kraus \& Litzenberger (1973). The second M\&M's proposition says that benefits, obtained from the increased use of the low cost debt and decreased use of the high cost equity, are completely offset by the increase in the risk level of equity. Shortly, leverage has no effect on the cost of capital.

In 1961, M\&M developed the dividend irrelevance proposition, which implied that the value of a firm is unaffected by the distribution of dividends, but is solely determined by the earning power and risk of its assets (Miller \& Modigliani, 1961). Two years later, M\&M (1963) developed the investor indifference proposition, which says that equity-holders are indifferent about a firm's financial policy, the 
thesis which was later deeply elaborated by Stiglitz $(1969 ; 1974)$. In their latest work, M\&M introduced corporate taxes and showed that leverage increases a firm's value because interest costs are tax-deductible and consequently increase the income available to the shareholders. M\&M were, however, careful about implying that the value of the firm would be maximized when using 100 percent debt financing. They argued that some other forms of financing, like retained earnings, can be cheaper than debt, and that lenders can impose limitations that prevent too high indebtedness. They concluded that firms need to preserve a certain rate of flexibility in maintaining reserve borrowing capacity (Modigliani \& Miller, 1963).

Miller (1977) later introduced the effect of personal taxes and argued that in equilibrium, tax advantage of debt would be exactly offset by the increased personal taxation, which means that a shareholder would be indifferent to how much leverage the firm uses. He argued that if the optimal capital structure is simply a matter of rebalancing tax advantages against bankruptcy costs, why then the observed capital structures show so little variation over the time. Contrary, DeAngelo \& Masulis (1980) argued that Miller's theorem is extremely sensitive to the realistic and simple modifications in the corporate tax code. They included into the analysis a tax shield that is not a result of the interest costs (e.g. accounting depreciation, depletion allowance, and investment tax credits) and showed that there is a market equilibrium, where every firm has a unique optimal capital structure. DeAngelo \& Masulis continued that market prices reflect personal and corporate taxes in such a way that the bankruptcy costs are a significant consideration in a trade-off between interest tax-deductibility and risk of financial distress.

Modigliani (1980) summarized the M\&M's irrelevance theorem in the following way: "... with well-functioning markets (and neutral taxes) and rational investors, who can 'undo' the corporate financial structure by holding positive or negative amounts of debt, the market value of the firm - debt plus equity - depends only on the income stream generated by its assets. It follows, in particular, that the value of the firm should not be affected by the share of debt in its financial structure or by what will be done with the returns - paid out as dividends or reinvested (profitably)". However, at the same time Chen \& Kim (1979) made a synthesis of theoretical and empirical research, and figured out that the theory somehow acknowledges the benefits of debt on aggregate level but is unable to answer why firms are using risky debt on the individual level. Therefore it soon became clear that M\&M's irrelevance theorem could not exist in a real economy, and researchers came to the conclusion that the capital structure must be relevant for a market value of a firm. Different theories emerged, explaining which factors are the most relevant when management is trying to find the optimal source of financing, i.e. the capital structure that would maximize the market value of a firm. The two most important theories are the tradeoff theory and the pecking order hypothesis. 
Figure 3: Chronological overview of most often cited papers from the field of capital structure and connections among them

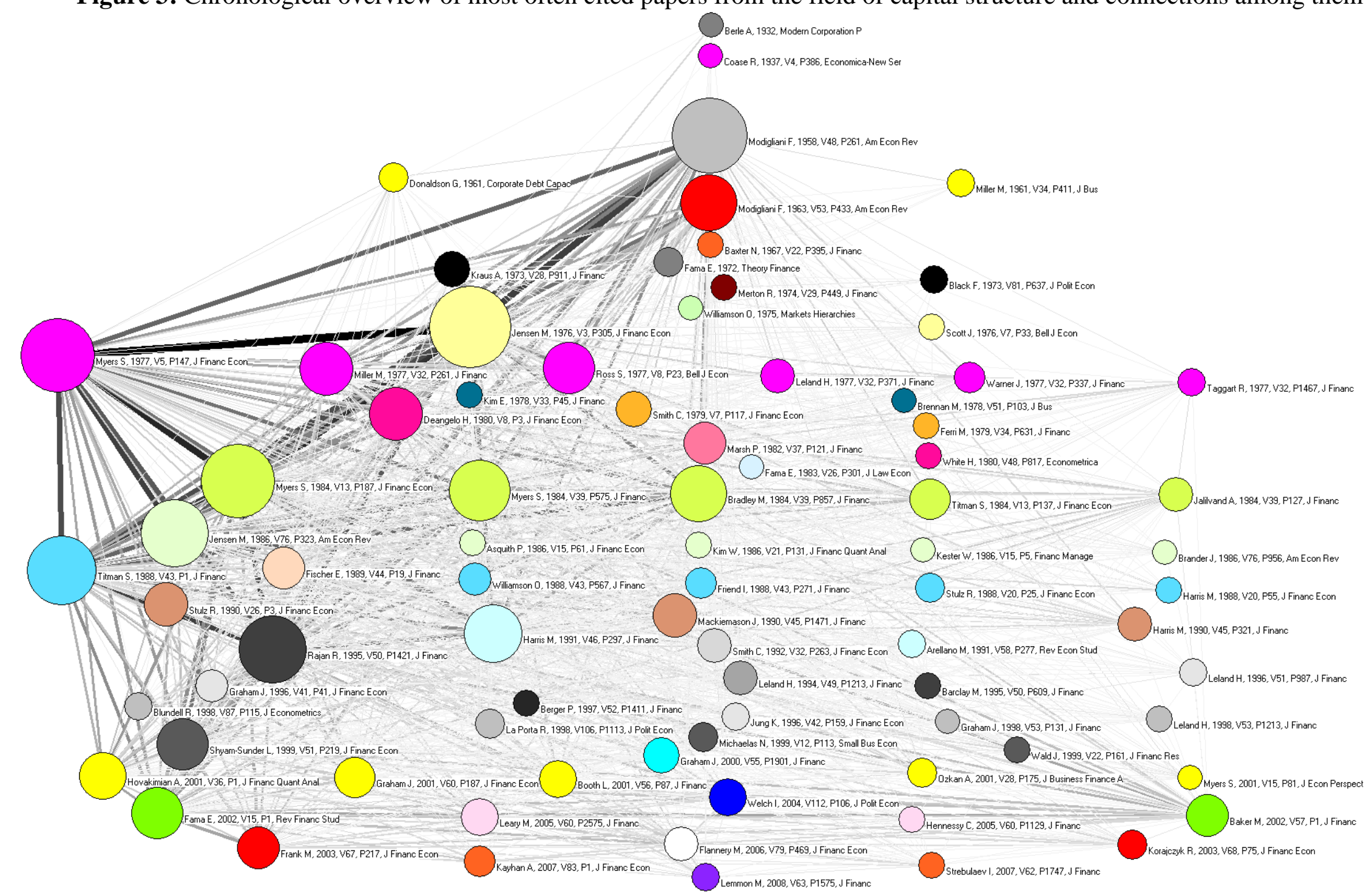

ISI Web of Science, 2013 \& BibExcel \& Pajek. 


\subsection{Trade-off theory}

Donaldson (1961) wrote an influential book called Corporate Debt Capacity, where he acknowledged that setting an appropriate limit for the borrowed amount of longterm debt is a major challenge for financial management. The reason is in the importance that a debt-equity ratio has for future solvency and profitability of a firm. Donaldson therefore tried to address a problem firms face every day: "Given the need for new permanent capital and ability to borrow, how does a company approach the determination of the wise and proper limit to such borrowing?" He argued that the main determinant of corporate debt capacity should be the probability of insolvency in times of recession, analyzed thorough firm's cash flows. His reasoning is popular even today, as for example in Kester et al. (2004), who argued that debt capacity should not be determined solely by industry averages or the availability of collateral, but also by borrower's ability to repay interests and the principal with a generated cash flow. Donaldson introduced the concept of risk and fear of insolvency with the help of objective risk assessment (management of cash flows) and subjective risk assessment (management inclination to risk-taking). It is generally accepted that the primary incentive to use long-term debt is the fact that debt is theoretically a cheaper source of financing than retained earnings or new equity issues. If the primary objective of a business is the maximization of net revenues, Donaldson (1961) continued, the use of debt should be a desirable source of financing and should be exercised as continuously as possible. The advantage of debt financing was especially well recognized in the period of high taxes during and after the World War 2 (Donaldson, 1961). It can be concluded that Donaldson was one of the first researchers who argued that the capital structure must be determined by weighing positive and negative effects of debt financing.

The trade-off theory developed as a response to the M\&M's irrelevance theorem. When M\&M (1963) added the effect of corporate tax, while ignoring the offsetting costs of debt (increased possibility of financial distress), 100 percent leverage was suggested as an optimal capital structure, although this was in contradiction with the observed firms' behavior. Kraus \& Litzenberg (1973) suggested that the best candidate for an offsetting cost of debt is a deadweight cost of bankruptcy, while Jensen \& Meckling (1976) more formally defined two types of conflicts, one resulting as a debt benefits and other as costs of debt financing. The first conflict, highly elaborated by Donaldson (1963), is between shareholders and managers (principal-agent problem), and is expressed in a form of debt benefit. The reasoning is that higher leverage reduces the principal-agent problem, because managers have less available free cash flow to invest it unwisely. The second conflict, Jensen \& Meckling continued, is between debt-holders and equity-holders, thoroughly presented by Smith \& Warner (1979). In that case, higher leverage increases agency costs of debt, because benefits are borne primarily by equity-holders, while costs by debt-holders. Optimal capital structure can then be found by trading-off benefits and costs of debt, which is the basic idea of the static version of trade-off theory. Myers (1984) later argued that a firm, which follows the trade-off theory, sets target 
leverage and then gradually moves toward that target - the main idea of the dynamic version of trade-off theory, which has become popular more recently.

Jensen \& Meckling (1976) claimed that M\&M (1963) were unable to offer an adequate theory of the observed capital structures. Similarly, Fama \& Miller (1972) wrote the following sentence: "We must admit that at this point there is little in the way of convincing research, either theoretical or empirical, that explains the amount of debt that firms do decide to have in their capital structure." Jensen \& Meckling (1976) argued that agency costs provide strong reasons for dependency between probability distribution of future cash flow and capital/ownership structure. They argued that while introduction of bankruptcy costs and presence of tax subsidies leads to the theory of optimal capital structure, that theory has serious drawback since it implies that no debt should ever be used in the absence of tax subsidies in case of positive bankruptcy costs. However, because firms have been using debt already when there were no tax benefits on interest costs, there must be some additional determinants of corporate capital structure. Moreover, neither the bankruptcy costs nor the tax subsidies can explain the use of preferred stocks or warrants, even more, theory says nothing about division of equity claims between insiders and outsiders. Researchers thus started arguing that bankruptcy costs themselves are unlikely to be the main determinant of a firm's capital structure because empirical research showed (e.g. Warner (1977)) that these costs represent very small percent of a firm's value. On the other hand, Baxter (1967) and Stanley \& Girth (1971) showed that for smaller firms this percentage can be considerably higher. Furthermore, Kim (1978) was one of the important advocators of the idea that firm reaches an optimal capital structure at level of indebtedness far below theoretically proposed 100 percent, as argued by some researchers before him. He continued that only when the target debt level is strictly lower than a firm's debt capacity, the firm can search for its optimal tradeoff between the tax advantage of debt and the cost of bankruptcy. Value of a firm can therefore be defined as the value of equity only financed firm, increased for the value of the tax savings and decreased for the value of the costs of financial distress. Value of the firm is therefore maximized at less than 100 percent debt financing (Morris, 1982).

According to the trade-off theory, there exists the optimal capital structure. The theory describes the firm's optimal capital structure as a mix of financing that equates the marginal costs to marginal benefits of debt financing (Lemmon \& Zender, 2010). However, it is important to distinguish between the static trade-off theory, where firm balances tax savings of debt against deadweight bankruptcy costs, and more recently introduced dynamic trade-off theory. A firm is said to follow the static tradeoff theory when firm's leverage is determined by a single period trade-off between the tax benefits of debt and the deadweight costs of bankruptcy (Frank \& Goyal, 2008). However, the main drawback of this theory is that it says nothing about a mean reversion of leverage. Consequently, the dynamic trade-off theory developed, proposing that a firm exhibits the target adjustment behavior if it has the target leverage and if deviations from that target are gradually eliminated over the time. The dynamic trade-off theory has advanced in recent years because it offers a good 
explanation of tendency movements of leverage, the role of profits, the role of retained earnings and the path dependency. Frank \& Goyal (2008) concluded that the target adjustment hypothesis receives much better empirical support than did either the static trade-off theory or the pecking order hypothesis, which is presented in the next section. An interesting overview of convergence toward the target capital structure is given by Lemmon et al. (2008). They clearly show that although leverage ratios exhibit persistence, there is a strong convergence toward the moderate indebtedness. Moreover, many researchers numerically estimated the speed of convergence. The majority of past empirical research on convergence is based on partial adjustment models, where average yearly rate of adjustment toward the predefined target is estimated, i.e. the speed. The most recent published speed estimates are 31 percent per year by Flannery \& Rangan (2006), 25 percent by Lemmon et al. (2008), 23 percent by Huang \& Ritter (2009), 22 percent by Byoun (2008), 7-18 percent by Fama \& French (2002), to practically zero by Baker \& Wurgler (2002), and Welch (2004). Nevertheless, Frank \& Goyal (2009) performed a comprehensive review of past empirical studies that examined the determinants that had a significant power at explaining observed capital structures and that gave consistent findings over many tests (e.g. Rajan \& Zingales (1995)). The six main determinants are industry median leverage (firms in industries in which the median firm has high leverage tend to have higher leverage), tangibility (firms that have more tangible assets tend to have higher leverage), profits (firms that have more profits tend to have lower leverage), firm size (firms that have larger assets or higher sales tend to have higher leverage), market-to-book-assets ratio (firms that have a high market to book ratio tend to have lower leverage), and inflation (when inflation is expected to be high, firms tend to have high leverage). Frank \& Goyal concluded that these six determinants explain 27 percent of the variation of leverage.

\subsection{Pecking order hypothesis}

Conflicts, related to the existence of inside information, were the main driver of the development of the theory of asymmetric information, under which managers and owners have more accurate information about a firm's true performance than those who lend the money. This theory has evolved into two directions. The first direction is connected to Ross (1977) and Leland \& Pyle (1977), who argued that the choice of a firm's capital structure gives an important signal (inside information) to outside investors. The second direction is represented by Myers \& Majluf (1984) and Myers (1984), who argued that the capital structure is used to solve inefficiencies in the firm's investment decisions, which are caused by the information asymmetry. This direction is associated with the so called pecking order hypothesis (Myers \& Majluf (1984), Krasker (1986) and Narayanan (1988)). The costs and benefits of debt (tradeoff theory) are of secondary importance compared to the importance of costs which arise when a new equity is issued under the conditions of highly asymmetric information (Shyam-Sunder \& Myers, 1999).

Myers \& Majluf (1984) advocated the idea that if the potential new shareholder is 
not equally informed as the existing shareholders, the former one will underprice new equity issues, the problem called "adverse selection". That would primarily cause a loss to the existing shareholders. The problem can be mitigated by giving priority to all other types of financing before issuing a new equity. These other types of financing are retained earnings and different forms of debt. This behavior is called the pecking order hypothesis. As a direct consequence, share price should fall after the announcement of new equity issue. Krasker (1986) confirmed this finding and additionally showed that the larger the stock issue, the larger will the fall in stock price be. This problem can result in underinvestment, which is more severe for firms with relatively low levels of tangible assets (Harris \& Raviv, 1991). Myers (1984) summarized the pecking order hypothesis: a firm is said to follow a pecking order if it prefers internal to external financing and debt to equity, when external financing is used. A more recent empirical analysis of the pecking order theory was performed by Frank \& Goyal (2003), who found that internal financing is often not sufficient to cover investment spending, which means that external financing is heavily used, often prioritizing debt.

\subsection{Industrial organization}

Capital structure models that are based on industrial organization theory can be divided into two groups. The first group of research explains relations between firm's capital structure and firm's strategy, while the second group of research explains relations between firm's capital structure and the characteristics of its products and inputs (Harris \& Raviv, 1991). Brander \& Lewis (1986) and Maksimovic (1988) were the initiators of the idea that financial theory of maximizing shareholders' value can be linked to industrial organization, where researchers typically used assumption of maximization of a total profit. These authors referred to the finding of Jensen \& Meckling (1976) that increased leverage encourages equity holders to accept riskier strategies. In Brander \& Lewis (1986) model, oligopolists increased the risk through aggressive production policy, and in order to finance it, firms in a subsequent Cournot game choose higher and higher levels of debt. As a result, Brander \& Lewis argued, oligopolists will often use more debt financing compared to monopolists or firms in competitive markets. Additionally, debt will be of long-term nature. Maksimovic (1988) also proved that debt capacity is increased with the elasticity of the demand.

The second group of research is concentrated around Titman's (1984) observations that customers and suppliers of unique and durable products would bare higher costs if a firm goes bankrupt, which means that such firms will be less indebted, ceteris paribus. When it is likely that a firm will stop operating, these costs are transferred to the shareholders through lower product prices. Titman argued that capital structure can be used to commit the shareholders to have an optimal liquidation policy. He showed that firms with higher costs of liquidation will use lower amounts of debt. Maksimovic \& Titman (1991) found evidence that even consumer of non-durable goods and services (e.g. hospitals, pharmaceuticals, and air travels) are concerned 
with the financial status of the producer, especially because of safety issues (e.g. in order to avoid bankruptcy, firm can reduce the quality of the products).

\subsection{Market timing theory}

The market timing plays an important role in describing observed capital structures . That was proposed already by Myers (1984), but it became more popular recently (e.g. Berry et al. (2008)). Graham \& Harvey (2001) found empirical support that management actively uses market timing when deciding whether to issue debt or equity - they found that firms issue equity after the increases of stock prices. Baker \& Wurgler (2002) argued that capital structure can best be understood as the cumulative effect of past attempts to time the market. Frank \& Goyal (2009) summarized this theory as management analyzing the current market conditions in debt and equity markets. When a firm needs new financing, management uses the type of financing which is more favorable at the moment. If neither of them looks favorable, management can defer the issuances. On the other hand, if current conditions look unusually favorable, funds may be raised even if the firm currently does not need new funds. The shortfall of this theory is that it cannot be linked with the traditional determinants of capital structure; however, it suggests that stock returns and debt market conditions are important when management is evaluating capital structure decisions (Frank \& Goyal, 2009).

\section{Conclusions}

This paper demonstrates how bibliometrics can be used as an educational tool, and be applied to a chosen field of literature. Firstly, a comprehensive dataset of papers can be obtained from ISI Web of Science. Secondly, once a set of relevant papers is selected, software BibExcel offers a great variety of tools for performing bibliometric analyses. Thirdly, software Pajek allows numerous graphical presentations of bibliometric information.

The graphical analysis shows (see Figure 3) that the modern capital structure theory began in the late fifties with the irrelevance theorem, and that it emerged from the neoclassical theory of the firm, which can be traced back into 1930s with works of Berle \& Means (1932) and Coase (1937). In 1958, Modigliani \& Miller introduced the irrelevance theorem, which stated that a capital structure does not affect a firm's value. The theorem was later modified with the inclusion of tax-deductibility of interest on debt (i.e. tax shield), which led to the conclusion that a firm's value is maximized at 100 percent of debt financing. Since the theorem was in contradiction with observed behavior, many researchers started arguing that in the real world capital structure does matter. The main argument was that with a high level of leverage, the risk of financial distress becomes significant and real. As a result, two theories of a firm's capital structure emerged: the trade-off theory (Jensen \& Meckling, 1976), and the pecking order hypothesis (Myers \& Majluf, 1984), both 
trying to explain a firm's observed behavior of capital structure choices. The basic idea of the trade-off theory is that firm's optimal capital structure is determined as the mix of financing that equates the marginal costs to marginal benefits of debt financing (Lemmon \& Zender, 2010). More recently, the dynamic version of tradeoff theory received high attention. It concentrates on gradual adjustments toward the target capital structure, and tries to explain temporary deviations from the target, defined by traditional trade-off determinants (e.g. tangibility of assets, profitability, size, etc.). A strong gradual convergence toward the target capital structure was empirically shown by Lemmon et al. (2008). Frank \& Goyal (2008) concluded that the target adjustment hypothesis receives a strong empirical support. In parallel to the trade-off theory, the pecking order hypothesis was developed. It prescribes the order of financing, which would maximize a firm's value. Myers (1984) summarized that a firm is said to follow a pecking order if it prefers internal to external financing and debt to equity, when external financing is used. Unlike the trade-off theory, it assumes that a firm does not have a target capital structure. Furthermore, two alternative theories for explanation of observed capital structure behavior emerged. First theory concentrates on products a firm produces. Firms that produce unique, durable products were found to have statistically lower indebtedness, because such firms have high costs of financial distress. Similarly, firms that offer products and services where safety issues are of high importance (e.g. hospitals, pharmaceuticals, and air travels) are less indebted (Maksimovic \& Titman, 1991). Second theory, equity market timing, was highly elaborated by Baker \& Wurgler's (2002). They found that past variation in market-to-book ratio has the strongest explanatory power of observed capital structure. The idea is that management is trying to exploit irrational investors by issuing equity when they are overly enthusiastic (e.g. Graham \& Harvey (2001)).

\section{References}

[1] Baker, M., \& Wurgler, J. (2002). Market Timing and Capital Structure. The Journal of Finance, 57 (1), 1-32.

[2] Batagelj, V., \& Mrvar, A. (1998). Pajek - program for large network analysis. Connections, 21 (2), 47-57.

[3] Baxter, N. D. (1967). Leverage, Risk of Ruin and Cost of Capital. The Journal of Finance, 22 (3), 395-403.

[4] Bayer, A. E., Smart, J. C., \& McLaughlin, G. W. (1990). Mapping Intellectual Structure of a Scientific Subfield through Author Cocitations. Journal of the American Society for Information Science, 41 (6), 444-452.

[5] Berle, A. A., \& Means, G. C. (1932). The Modern Corporation and Private Property. New Jersey: Transaction Publishers.

[6] Berry, C. B., Mann, S. C., Mihov, V. T., \& Rodriguez, M. (2008). Corporate debt issuance and the historical level of interest rates. Financial Management, 37 (3), 413-430. 
[7] Brander, J. A., \& Lewis, T. R. (1986). Oligopoly and Financial Structure: The Limited Liability Effect. American Economic Review, 76 (5), 956-970.

[8] Byoun, S. (2008). How and When do Firms Adjust their Capital Structures towards Targets? The Journal of Finance, 63 (6), 3069-3096.

[9] Chen, A. H., \& Kim, H. E. (1979). Theories of Corporate Debt Policy: A Synthesis. The Journal of Finance, 34 (2), 371-384.

[10] Coase, R. H. (1937). The Nature of the Firm. Economica, 4 (16), 386-405.

[11] De Bellis, N. (2009). Bibliometrics and Citation Analysis. Lanham: Scarecrow Press.

[12] DeAngelo, H., \& Masulis, R. W. (1980). Optimal Capital Structure under Corporate and Personal Taxation. Journal of Financial Economics, 8 (1), 3-29.

[13] Demsetz, H. (1967). Toward a Theory of Property Rights. American Economic Review, 57 (2), 347-359.

[14] Donaldson, G. (1961). Corporate Debt Capacity: A study of corporate debt policy and the determination of corporate debt capacity. Boston: Harvard University.

[15] Donaldson, G. (1963). Financial Goals: Management vs. Stockholders. Harvard Business Review, 41 (3), 116-129.

[16] Dospinescu, N., Tătăruşanu, M., Butnaru, G. I., \& Berechet, L. (2011). The Perception of Students from the Economic Area on the New Learning Methods in the Knowledge Society. The AMFITEATRU ECONOMIC journal, 13 (30), 527-543.

[17] Fama, E. F., \& French, K. (2002). Testing the trade-off and the Pecking order Predictions about Dividends and Debt. Review of Financial Studies, 15 (1), 1 33.

[18] Fama, E. F., \& Miller, M. H. (1972). The theory of finance. New York: Holt, Rinehart and Winston.

[19] Flannery, M. J., \& Rangan, K. P. (2006). Partial adjustments toward target capital structures. Journal of Financial Economics, 79 (3), 469-506.

[20] Frank, M. Z., \& Goyal, V. K. (2003). Testing the pecking order theory of capital structure. Journal of Financial Economics, 67 (2), 217-248.

[21] Frank, M. Z., \& Goyal, V. K. (2008). Trade-off and Pecking Order Theories of Debt. In E. Eckbo, The Handbook of Empirical Corporate Finance (pp. 135197). Elsevir Science.

[22] Frank, M. Z., \& Goyal, V. K. (2009). Capital Structure Decisions: Which Factors are Reliably Important? Financial Management, 38 (1), 1-37.

[23] Graham, J. R., \& Harvey, C. R. (2001). The theory and practice of corporate finance: evidence from the field. Journal of Financial Economics, 60 (2-3), 187-243.

[24] Harris, M., \& Raviv, A. (1991). The Theory of Capital Structure. The Journal of Finance, 46 (1), 297-355.

[25] Hunag, R., \& Ritter, J. R. (2009). Testing Theories of Capital Structure and Estimating the Speed od Adjustment. Journal of Financial and Quantitative Analysis, 44 (2), 237-271.

[26] Jensen, M. C., \& Meckling, W. H. (1976). Theory of the Firm: Managerial Behavior, Agency costs and Ownership Structure. Journal of Financial Economics, 3 (4), 305-360. 
[27] Kester, G. W., Hoover, S. A., \& Pirkle, K. M. (2004). How Much Debt Can a Borrower Afford? The RMA Journal, 87 (3), 46-51.

[28] Kim, E. H. (1978). A Mean-Variance Theory of Optimal Capital Structure and Corporate Debt Capacity. The Journal of Finance, 33 (1), 45-63.

[29] Krasker, W. S. (1986). Stock Price Movements in Response to Stock Issues under Asymmetric Information. The Journal of Finance, 41 (1), 93-105.

[30] Kraus, A., \& Litzenberger, R. H. (1973). A State-Preference Model of Optimal Financial Leverage. The Journal of Finance, 28 (4), 911-922.

[31] Leland, H. E., \& Pyle, D. H. (1977). Informational Asymmetries, Financial Structure, and Financial Intermediation. Journal of Finance, 32 (2), 371-387.

[32] Lemmon, M. L., \& Zender, J. F. (2010). Debt Capacity and Tests of Capital Structure Theories. Journal of Financial and Quantitative Analysis, 45 (5), 1161-1187.

[33] Lemmon, M. L., Roberts, M. R., \& Zender, J. F. (2008). Back to the Beginning: Persistence and the Cross-Section of Corporate Capital Structure. The Journal of Finance, 63 (4), 1575-1608.

[34] Maksimovic, V. (1988). Capital Structure in Repeated Oligopolies. RAND Journal of Economics, 19 (3), 389-407.

[35] Maksimovic, V., \& Titman, S. (1991). Financial Policy and reputation for product quality. Review of Financial Studies, 4 (1), 175-200.

[36] Miller, M. H. (1977). Debt and Taxes. The Journal of Finance, 32 (2), 261-275.

[37] Miller, M. H., \& Modigliani, F. (1961). Dividend Polity, Growth, and the Valuation of Shares. Journal of Business, 34 (4), 411-433.

[38] Modigliani, F. (1980). Introduction. In A. Abel, The Collected Papers of Franco Modigliani, volume 3 (pp. xi-xix). Cambridge, Massachusetts: MIT press.

[39] Modigliani, F., \& Miller, M. (1958). The cost of Capital, Corporation Finance and the Theory of Investment. The American Economic Review, 48 (3), 261297.

[40] Modigliani, F., \& Miller, M. (1963). Corporate Income Taxes and the Cost of Capital: A correction. The American Economic Review, 53 (3), 433-443.

[41] Morris, J. R. (1982). Taxes, Bankruptcy Costs and the Existence of an Optimal Capital Structure. The Journal of Financial Research, 5 (3), 285-299.

[42] Myers, S. C. (1984). The Capital Structure Puzzle. The Journal of Finance, 39 (3), 575-592.

[43] Myers, S. C., \& Majluf, N. S. (1984). Corporate financing and investments decisions when firms have information the investors do not have. Journal of Financial Economics, 13 (2), 187-221.

[44] Narayanan, M. P. (1988). Debt Versus Equity under Asymmetric Information. Journal of Financial and Quantitative Analysis, 23 (1), 39-51.

[45] Persson, O. (2009). Making Google Maps. Retrieved 3 1, 2013, from http://www8.umu.se/inforsk/Bibexcel/

[46] Persson, O. (2009). Mapping science using Bibexcel and Pajek. European Summer School for Scientometric. Retrieved 2 28, 2013, from http://www8.umu.se/inforsk/Bibexcel/

[47] Persson, O., Danell, R., \& Wiborg Schneider, J. (2009). How to use Bibexcel for various types of bibliometric analysis. In F. Astrom, R. Danell, B. Larsen, 
\& J. Wiborg Schneider, Celebrating Scholarly Communication Studies: A Festschrift for Olle Persson at his 60th Birthday (pp. 9-24). ISSI.

[48] Plumb, I., \& Zamfir, A. (2011). A Possible Model for Developing Students' Skills within the Knowledge-Based Economy. The AMFITEATRU ECONOMIC journal, 13 (30), 482-496.

[49] Pocatilu, P., \& Ciurea, C. (2011). Modern Solutions For Economic Higher Education In The Knowledge-Based Society. The AMFITEATRU ECONOMIC journal, 13 (30), 497-511.

[50] Rajan, R. G., \& Zingales, L. (1995). What Do We Know about Capital Structure? Some Evidence from International Data. Journal of Finance, 50 (5), 1421-1460.

[51] Robichek, A. A., \& Myers, S. C. (1966). Problems in the Theory of Optimal Capital Structure. Journal of Financial and Quantitative Analysis, 1 (2), 1-35.

[52] Ross, S. A. (1977). The Determination of Financial Structure: The IncentiveSignalling Approach. The Bell Journal of Economics, 8 (1), 23-40.

[53] Shyam-Sunder, L., \& Myers, S. C. (1999). Testing static tradeoff against pecking order models of capital structure. Journal of Financial Economics, 51 (2), 219-244.

[54] Smith, C. W., \& Warner, J. B. (1979). An analysis of Bond Covenants. Journal of Financial Economics, 7, 117-161.

[55] Stanley, D. T., \& Girth, M. (1971). Bankruptcy: Problem, Process, Reform. Washington: Brookings Institution.

[56] Stiglitz, J. E. (1969). A Re-Examination of the Modigliani-Miller Theorem. The American Economic Review, 69 (5), 784-793.

[57] Stiglitz, J. E. (1974). On the Irrelevance of Corporate Financial Policy. The American Economic Review, 64 (6), 851-866.

[58] Thomson Reuters. (2013, 2 25). The Web of Science. New York, USA.

[59] Titman, S. (1984). The Effect of Capital Structure on a Firm's liquidation decision. Journal of Financial Economics, 13 (1), 137-151.

[60] Warner, J. B. (1977). Bankruptcy Costs: Some Evidence. Journal of Finance, 32 (2), 337-347.

[61] Welch, I. (2004). Capital Structure and Stock Return. Journal of Political Economy, 112 (1), 106-131.

[62] White, H. D., \& Belver, G. C. (1981). Author Cocitation: A Literature Measure of Intellectual Structure. Journal of the American Society for Information Science, 32 (3), 163-171. 